\title{
Ecology and Environmental Impact of Myriophyllum heterophyllum, an Aggressive Invader in European Waterways
}

\author{
Elisabeth M. Gross ${ }^{1} * * \mathbb{D}$, Hélène Groffier ${ }^{1}$, Cécile Pestelard ${ }^{2}$ and Andreas Hussner ${ }^{3}$ \\ 1 CNRS, LIEC, Université de Lorraine, F-57000 Metz, France \\ 2 VNF/DT Nord-Est, AEME, Gestion des Milieux, 169, rue de Newcastle, CS 80062, 54036 Nancy, CEDEX, \\ France \\ 3 Leibniz-Institute of Freshwater Ecology and Inland Fisheries, Müggelseedamm 301, 12587 Berlin, Germany \\ * Correspondence: gross5@univ-lorraine.fr; Tel.: +33-372-748-998
}

Received: 29 February 2020; Accepted: 24 March 2020; Published: 30 March 2020

\begin{abstract}
The submerged evergreen aquatic plant Myriophyllum heterophyllum is among the worst invasive species in Europe, causing severe problems especially in navigation channels but also lentic systems. This review aims to provide a comprehensive overview and update on the current distribution and risks associated with this species in Europe and elsewhere. We provide an evaluation of current identification keys since misidentification can underestimate the extent of its spread. In addition, hybridization with other milfoil species has been reported in North America but seems unlikely in Europe. We further describe in detail the ecology, specifically resource requirements and biotic interactions with other plants, herbivores and pathogens as well as the spread potential of the species. Good knowledge of the autecology and synecology of this species should allow some conclusions about environmental factors possibly related to its invasive growth and is mandatory for the preparation of species-specific management measures. Finally, we outline the status of regulations coming into effect in member states of the European Union (EU) and provide an overview of applied and potential management practices.
\end{abstract}

Keywords: Haloragaceae; invasion spread; ecological niche; alkalinity; nitrogen

\section{Introduction}

Alien Myriophyllum heterophyllum Michx., 1803 (Haloragaceae) is becoming a species of extreme concern within some European countries, as it is currently spreading very fast, particularly in artificial waterways (channels), such as in Northeast France (Figure 1). Hussner (2012) described it in six European countries (Austria, Belgium, France, Germany, the Netherlands and Spain) [1]. By that time, the species was only on the Alert List of the European and Mediterranean Plant Protection Organization (EPPO), but has moved up to A2 level in 2015 after a comprehensive pest risk assessment (PRA) of the species was conducted [2]. A2 level lists species locally present in the EPPO region and recommended for regulation as quarantine pests by EPPO member countries [3]. The EU Regulation 1143/2014 on the prevention and management of the introduction and spread of invasive alien species [4] outlines that all member states should "prevent the introduction of, control or eradicate those alien species which threaten ecosystems, habitats or species". It is listing 66 invasive alien species of EU concern, including M. heterophyllum since 2017 [5]. 

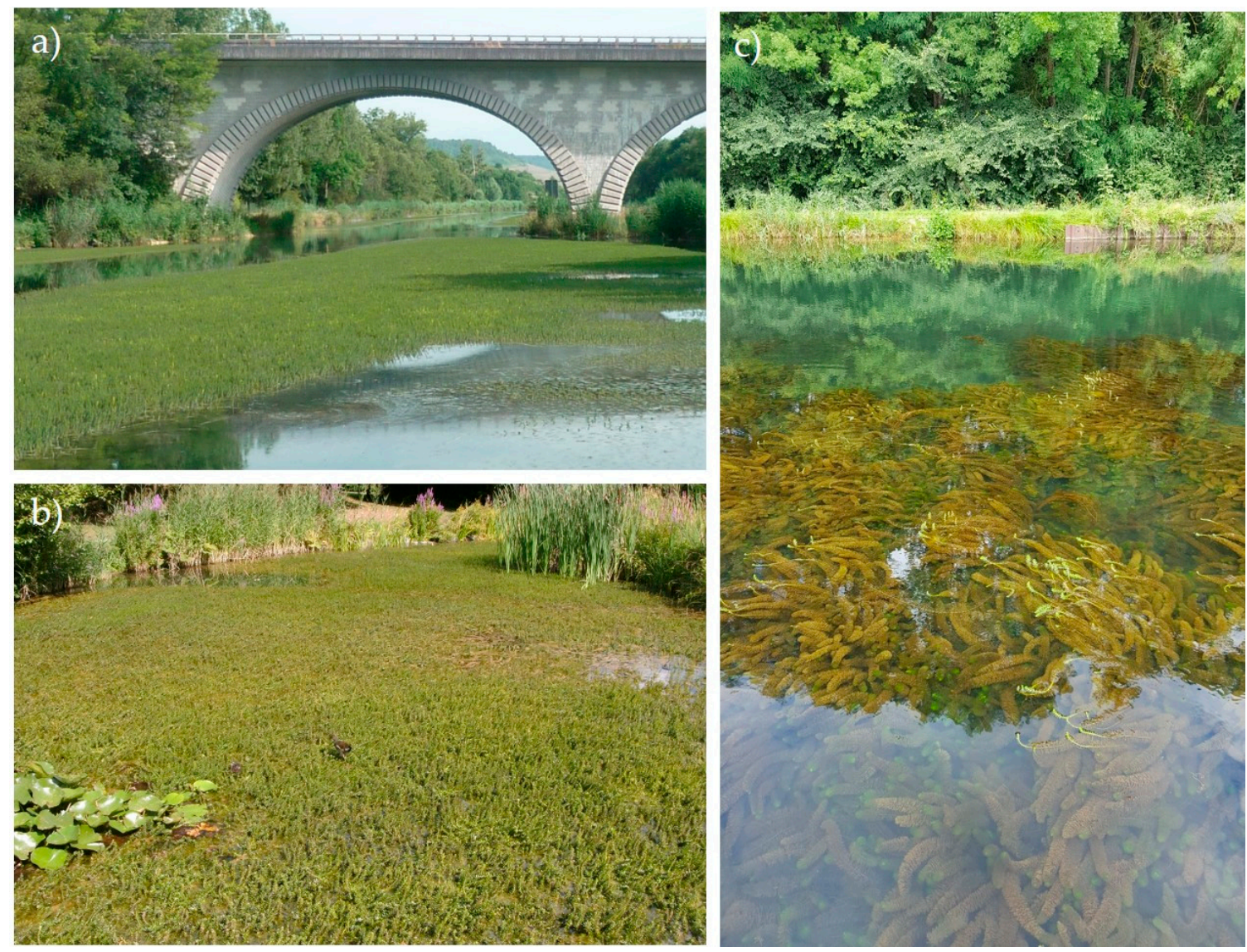

Figure 1. Systems invaded by Myriophyllum heterophyllum. (a,c) navigation channels in Northeast France (Photos C. Pestelard); (b) pond on the campus of Düsseldorf University, Germany (Photo A. Hussner).

Local handling of invasions at an early stage is a crucial point, but often not sufficient or successful, despite the above-described increased awareness on potential risks for aquatic ecosystems. The most important reasons are difficulties in species identification, gaps in predicting possible habitats that might be invaded in the near future, and the difficulty to manage massive infestations, as most applied techniques only cause short-lived reductions, followed by another strong expansion and even further dispersal.

The available scientific and 'grey' literature on M. heterophyllum is larger than one might first assume. However, to our knowledge, no review has been published so far compiling different information about this species. In the following, we focus on the origin and invasive spread (Section 2), the morphological and molecular taxonomy (Section 3), the autecology and synecology (Section 4), the environmental factors influencing growth and dispersal (Section 5) and the status of regulation and control measures (Section 6). With this comprehensive overview, we hope to increase the awareness for the high risk of invasion of this species in Europe and elsewhere, and aim to provide criteria for clear identification and an estimate of future impacted systems to allow control measures at an early stage. 


\section{Origin and Invasive Spread}

Myriophyllum heterophyllum, or broadleaf water milfoil, is native to parts of North America. Aiken (1981) reports its distribution from Virginia to Florida, northward to Ontario and Michigan and westward to Missouri and Texas [6], but it is not considered native in the Northeast or the Western US. The author states that she never found the species in Minnesota, although some authors reported it there (Fassett 1940 and Reed 1977, cited in [6]). While it is currently of pressing concern in Europe, as described below, it has also expanded into New England and recently to some western states of the US (California, Oregon, Washington State) [7,8]. The rapid spread of the species in New England happened since the 1980s. The first recorded evidence for this species is from Bridgeport, Connecticut in 1932 [9]. In this publication, Les and Meerhof (1999) listed in detail the recension of herbarium specimens in New England, and the verification of some misidentified records, mostly as M. verticillatum, but also as Proserpinaca palustris. They also cite two papers, (Tricker 1897; Bisset 1907) cited in [9], recommending the use of M. heterophyllum for aquarium and water garden culture at that time. In Washington State, the species was first listed in 2008, is of great concern and since January 2010 on the quarantine list [10].

In Canada, the species is considered indigenous in the East (New Brunswick, Prince Edward Island, Quebec and Ontario) and introduced in British Columbia according to 'Canadensys' [11], but this source contains no reports for Alberta, as suggested in [12]. Another database [13], based on [11] lists the species for New Brunswick and Prince Edward Island. It is native in Guatemala and Mexico; the 'tropicos' website is also extremely detailed in listing the distribution, specimens collected and associated references all across the Americas [12,14]. The species is mentioned as 'naturalized' in Southern China, in the Guangdong province; herbarium specimens erroneously labeled as M. verticillatum have been corrected to M. heterophyllum [15].

In Europe, M. heterophyllum has been described for Austria, Belgium, France, Germany, Hungary, the Netherlands, Spain, Switzerland [1,2] and recently Croatia [16]. The earliest findings in Europe in natural waterbodies date from the 1940s, ca. 1942 in Saxony (Stricker 1962), ca. 1945 in Austria (Melzer 1965) and 1946 in Switzerland (Janchen 1966; Egloff 1974), all cited in [17]. However, there seems to be no direct link with transcontinental transport during the Second World War from the United States. Rather the species had been voluntarily imported, such as already in 1906 to Darmstadt, Germany, initially under the name $M$. tritoni [17].

Currently, the status in these European countries is quite variable and not easy to verify. A problem for the exact identification and current distribution lies in the heterogeneous information found in different databases. Not all sites report the actual spread of the species, or they differ in, e.g., the time of introduction and criteria for identification. We, therefore, have updated the available information by web searches and contacting relevant persons directly, as indicated in the following.

In Austria, two locations have been listed (Styria: Oberdorf near Weiz; Carinthia: Faaker Lake), but the recent status is unclear [18]. The same is true for findings in Switzerland; one confirmed location around 1995 and two not confirmed locations observed in 1974/1975 are reported for the canton Zurich [19]. In Croatia, the species was found by chance in 2016 at one sampling site, Lake Desne, in the Neretva River Delta [16]. An extensive search of the whole delta in 2018 found 10-15 sites where the species could be identified based on the presence of floral spikes, and another 30-35 sites, where the clear identification is pending due to the presence of only submerged plant parts and/or the concurrent presence of M. verticillatum; it is unclear whether these sites already existed before or are recent expansions (N. Vukovic, personal communication). The species was present in Great Britain as mentioned in [16], and strong efforts have been taken to eradicate all known sites at an early stage (J. Newman, personal communication). The sole occurrence in Hungary observed in 2004 seems to have disappeared as the small pond, where it was observed, had frequently dried out in the past (Z. Barina, personal communication; [20,21]). In Spain, the first observations were from the Vizcaya Region (Northern Spain) in 1987 [22], and it was detected during 1995/1996 close to Valencia (Eastern Spain) [23]. However, it has not been found in a large sampling campaign in natural lakes all over the Spanish peninsular during 2019 (S. Calero, personal communication). Its 
presence seems to be confined to very few semi-natural waterbodies in these two regions, where the species has been maintained and managed for years [22,24]. In Belgium, the species was found in 2006 in large stands in canals close to Antwerp [25] and close to Namur (Bouxin and Lambinon 1996, cited in [12], thus appearing in very distant locations, suggesting that there were at least two invasion events. A regularly updated database exists for the Flemish region, recording already four findings for 2020 (I. Stiers, personal communication; [26]). It is, however, surprising to find no records for Wallonia, which is just north of the Grand Est region in France, where we recently observe so many large infestations. In the Netherlands, the first record is from 1999; from 2007 onward, it has been found in several canals and harbors; since 2016 it has been present throughout the southeast and central parts of the country [27] and has in the meantime expanded also to the north and some western areas [28]. A finding of extensive stands in 2003 is described in detail for a black water close to Venlo, not far from the German border [29]. A large collection of 38 specimens from the Netherlands and elsewhere is documented in Q-bank [30].

In Germany, M. heterophyllum is listed in 49 of the 3000 grid cells used to show the distribution of ferns and flowering plants. The earliest and most widespread populations are in eastern Germany (southern Brandenburg, Saxony, Saxony-Anhalt, Thuringia), mainly in canals such as the Elster-Saale Canal, followed by established populations in North-Rhine Westphalia and Lower Saxony, and in the past years, scattered findings in at least four other federal states were recorded [31]. The information base is increasing due to the demand of the EU Regulation 1143/2014 [4], requiring member states to report on recent findings of problematic species. The first documented large infestation in Germany was described for the harbor at Leipzig and the Elster-Saale Canal (Stricker 1962 cited in [17]). A second hot-spot is North Rhine-Westphalia, where the species appeared end of the 1970s in some lakes of the Ville, and later in lakes in the Düsseldorf area [32].

In France, the species was observed in July 2011 in a pond in the department Haute-Vienne [12], and the Resource Centre for Exotic Invasive Species describes it in the departments Landes, Rhône, Pyrénées-Atlantiques and Somme [33]. A short note in the CBNBP (Conservatoire Botanique National du Bassin Parisien) describes that it might have been present already at the end of the 1980s, was first identified in 1999 in the department Pyrénées-Atlantiques and further documented in several other departments (Ardennes, Marne, Haute-Marne) in Northeast France [34]. Our observations show that it is widespread in navigation channels in Northeast France. It was recently found in the Basin Vauban, Strasbourg, Alsace, France (N. Dubost provided material to E. Gross), and is possibly also widespread in other departments such as the Côte-d'Or (presence in the harbor at Saint-Jean-de-Losne (reference material available with the authors). We provide a detailed map of current observations as documented by the French Waterways Authority (VNF) (Figure 2). 


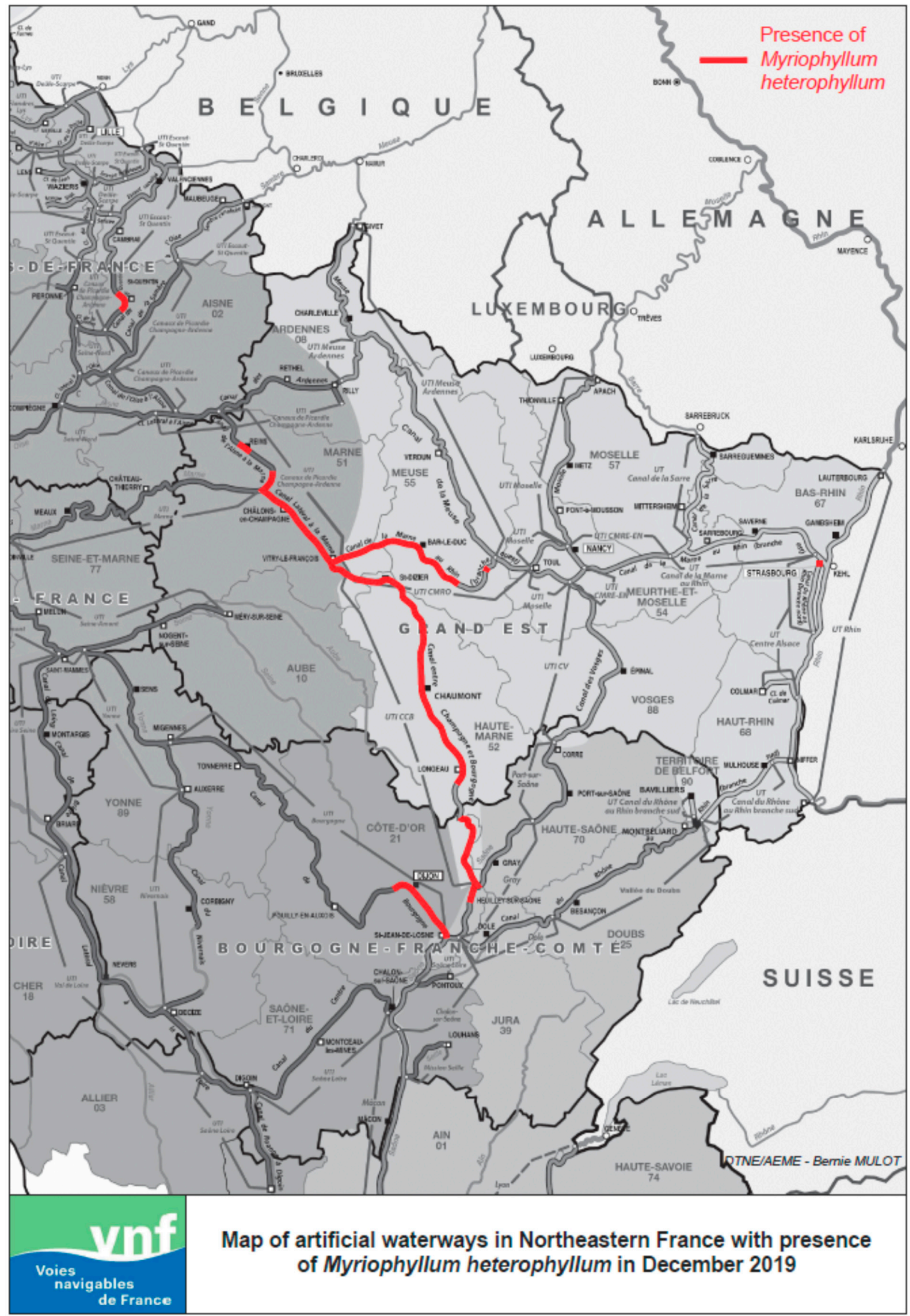

Figure 2. Presence of Myriophyllum heterophyllum in navigation channels in Northeast France as of December 2019, based on own observations or reported findings. Map established by C. Pestelard. 


\section{Morphological and Molecular Identification}

Recent phylogenetic analysis identifies the species as being a member of a clade of Myriophyllum endemic to North America including M. pinnatum Britton, Sterns and Poggenb., M. hippuroides Nutt. ex Torr. and A. Gray, M. farwellii Morong, M. humile Morong, M. laxum Schuttl. ex Chapm. and M. tenellum Bigelow [35].

Due to high similarities, particularly of the vegetative forms, M. heterophyllum can be misidentified in Europe with M. verticillatum or in North America with other native Myriophyllum species such as M. hippuroides, M. laxum or M. pinnatum. A useful diagnostic character seems to be the arrangement of leaves, particularly at the stem base; they are seemingly in whorls, but on a closer look arranged in a series of very short internodes alternating with long internodes [6]. Another good characteristic to distinguish $M$. heterophyllum from $M$. verticillatum seems to be the presence of turions (winter buds). Turions are abundant and tightly packed apices found on apical sections of M. verticillatum, and if at all present, they are larger and less compact on $M$. heterophyllum and found only at the base of the plants growing from the rhizomes, not along the erect stems [6]. The absence of turions was explicitly stated for material analyzed in North-Rhine Westphalia, and in the associated identification key [17]. Myriophyllum heterophyllum and M. hippuroides can be distinguished by differences in their floral spikes, such as the size of bracteoles and bracts and floral organ morphology (see [6] for details).

Clear taxonomic identification of $M$. heterophyllum can be done when floral spikes are present due to the mostly four red stigmata, only four stamina and the mostly laminate, non-dissected and slightly serrated bracts (Figure 3a,b) [17]. However, we also observed more dissected (comb-like) bracts on some floral spikes (Figure 3c,d), similar to those found, e.g., for M. verticillatum.


Figure 3. Morphological characteristics of Myriophyllum heterophyllum. (a-d) floral spikes with bracts and red stigmata; please note the different form of the bracts; for details, see text. (e,f) shoot section with detail of leaves slightly offset within a whorl (Photos (a) A. Hussner, (b-e) C. Pestelard, (f) N. Dubost). 
Distinguishing it in the vegetative state from native species is more difficult as described in North America [9] and Europe [17]. In Europe, a differentiation towards M. spicatum is relatively easy as the leaves of this species are shorter than internodes, at least at the lower stem. Further, M. spicatum has mostly four leaves per whorl while M. heterophyllum and M. verticillatum mostly have five, but see, e.g., [17] for variability in leaf number per whorl. More difficult is the differentiation towards M. verticillatum, which has a very similar habitus underwater (fox tail or 'queue de renard' which is what M. heterophyllum is called in France). Here clear criteria are the apical turions formed by M. verticillatum in the fall and the placement of leaves on the whorls. A slight offsetting of individual leaves within one whorl is a clear criterion for M. heterophyllum (Figure 3e,f). A very detailed comparison of the four native European Myriophyllum species has been published in German by Wimmer (1997) [17]. In addition to differences in leaf traits (number of leaves per whorl, leaf length and width, leaflet number, leaflet length and width, placement and distance of leaflets), he used the presence of glands at different places on the leaves as a criterion. However, our observations show that these are sometimes difficult to detect. Another criterion is the alternate placement of leaflets compared to opposite leaflets for M. verticillatum or the form of the end leaflet [17]. Depending on the habitat, leaves of M. heterophyllum can have carbonate incrustations specifically at high alkalinity, similar to M. spicatum, but this not the case for M. verticillatum, which uses only $\mathrm{CO}_{2}$ for photosynthesis.

Molecular taxonomy permits a clear distinction of Myriophyllum species and even of hybrids. ITS sequence data allowed identification by differences in restriction enzyme sites between $M$. heterophyllum and other species $[8,36]$. Hybrid vigor seems to be a factor promoting invasive growth of invasive Myriophyllum species, found for both M. heterophyllum and M. spicatum [37,38]. The hybrid identified in Northeast USA is M. heterophyllum $\times$ M. laxum (first described as M. heterophyllum $\times$ M. pinnatum $)[8,35,37,38]$. Yet, not all $M$. heterophyllum showing invasive behavior are hybrids [39]. Cryptic M. heterophyllum lineages might exhibit differences in their growth characteristics, and often the hybrids showed a higher biomass, plant size or branching level [38]. It is unlikely that hybrids with native European Myriophyllum species are present in Europe because apparently no viable seeds are formed here [2].

Based on the high concern for this species, various organizations have developed fact sheets (e.g., [27,40-42]) regrouping relevant information on, for example, morphological characteristics, habitat demands, invaded areas and/or control measures applied. We consider it important that those are updated regularly and should include the most distinguishing identification criteria (leaf morphology and leaf placement in whorls, floral spike traits) to enhance the distinction from similar native species. More information is also needed on the potential phenotypic plasticity of certain traits, as different environmental conditions will lead to differences in growth [38].

A terrestrial form of the plants can develop when stands of this species dry out. This was observed by Manuel (1973), cited in [6], who described that terrestrial plants had small shoots of maximum $10 \mathrm{~cm}$ height, with strongly cutinized leaves. Clumped plant remains left along the shoreline after management can survive in a terrestrial form [2,43] (Figure 4). It is currently unclear if these terrestrial forms can contribute to the spread of the species, but they are certainly able to regain vigorous growth when again being submerged in water. 


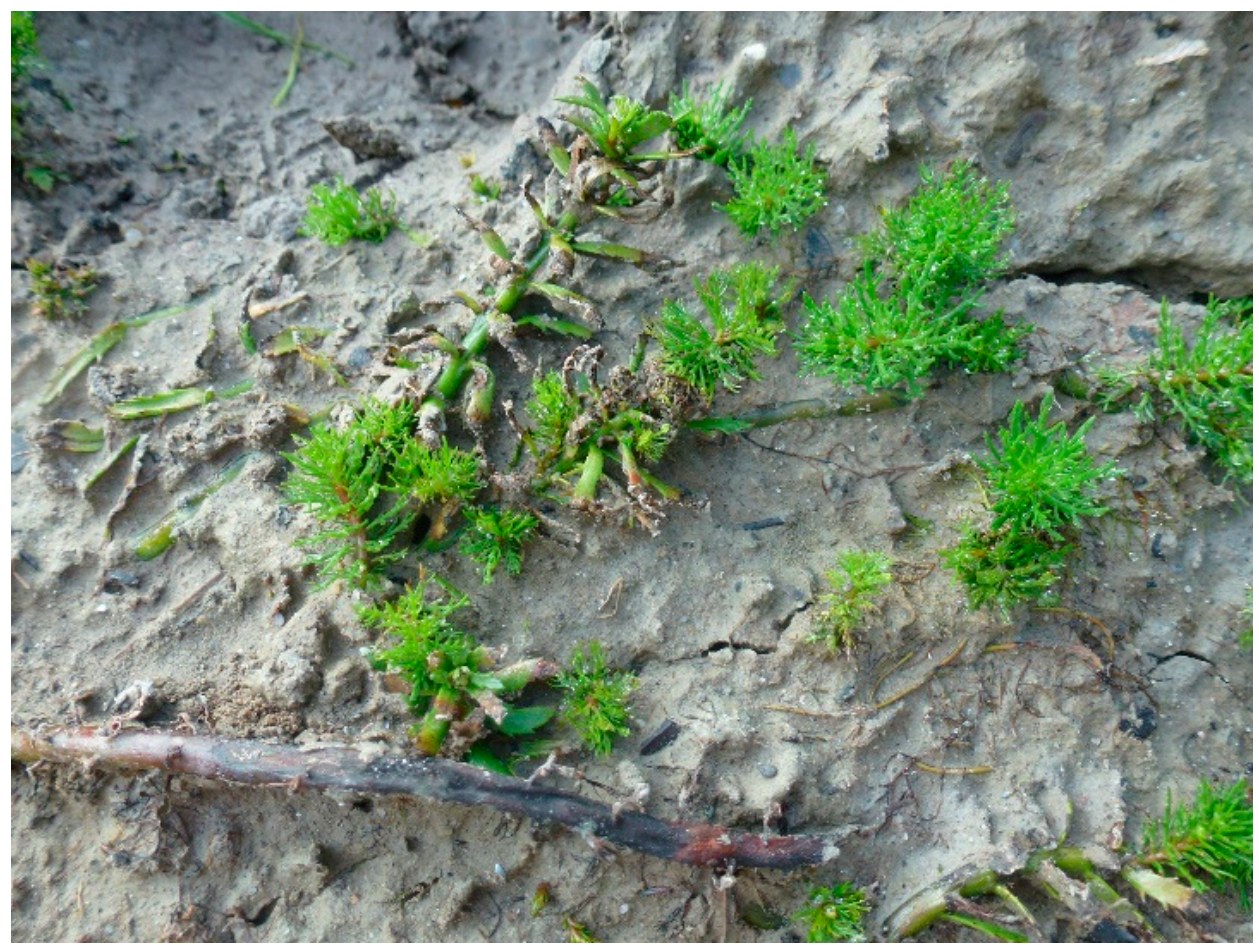

Figure 4. The terrestrial growth form of Myriophyllum heterophyllum. Photo A. Hussner.

\section{Autecology and Synecology}

\subsection{Autecology}

Myriophyllum heterophyllum is an evergreen species and thus can be found the whole year round. In addition, $M$. heterophyllum seems to form turions as winter buds on lower stem sections as vegetative overwintering organs [6], although these structures have not been observed from European stands so far. Even though no seed production is known from its European range, M. heterophyllum stands are reported as long-lasting. Seed production is known from North America [40], and seeds were found in a Mexican high-altitude wetland in depth up to $10 \mathrm{~cm}$ of the sediment, with the species still being part of the actively growing vegetation [44].

\subsubsection{Habitat and Water Physicochemical Conditions}

Myriophyllum heterophyllum grows in stagnant and slow-flowing waters, such as lakes, canals, ponds and slow-flowing rivers $[2,12,25,29,32,45]$. Even though the species was found to a maximum depth of $10 \mathrm{~m}$ in lakes, the highest biomass accumulation with up to $4 \mathrm{~kg} \mathrm{~m}^{-2}$ dry mass is reported from shallow sites accumulated from several years [2]. Artificial waterways seem to be a preferred habitat for the species as seen above, allowing its fast spread. In New England, its spread from Delaware northward was spotted along artificial waterways [9]. In Germany, one of its earliest findings was in the Elster-Saale Canal near Leipzig, Eastern Germany [46] and the current expansion in Northeast France is predominantly in canals.

Regarding alkalinity, Myriophyllum heterophyllum was reported from waters with low alkalinity in Connecticut, USA (2-6 $\mathrm{mg} \mathrm{CaCO}_{3} \mathrm{~L}^{-1}$ equivalent to $0.02-0.06 \mathrm{mM}$ alkalinity); in canals, sand and gravel pits or residual lakes formed after mining with alkalinities between 0 and $1.7 \mathrm{mM}$ [46]). In New England (D. Les, personal communication), M. heterophyllum is found more often in acidic, low alkalinity waters ( $\mathrm{pH}$ 6.0-7.9; alkalinity 0.1-1.3 mM), with variations among sites. Recent measurements in two canals in Northeast France showed its presence at high alkalinity of about 1.6-2.2 mM, suggesting that the species might have a wider amplitude than previously thought (Table 1). 
Table 1. Water analyses in sections of two navigation channels in Northeast France, the Canal from Champagne to Bourgogne (CCB) and the Canal from the Marne to the Rhine, Western Branch (CMRo).

\begin{tabular}{|c|c|c|c|c|c|c|c|c|c|c|c|c|c|c|c|}
\hline Channel & $\begin{array}{c}\text { Statistical } \\
\text { Details }\end{array}$ & $\mathrm{pH}$ & $\begin{array}{l}\text { Alk. } \\
(\mathrm{mM})\end{array}$ & $\begin{array}{c}\text { Cond. } \\
\left(\mu \mathrm{sm}^{-1}\right)\end{array}$ & $\begin{array}{c}\mathrm{N}-\mathrm{NO}_{2} \\
\left(\mu \mathrm{g} \mathrm{L}^{-1}\right)\end{array}$ & $\begin{array}{l}\mathrm{N}-\mathrm{NO}_{3} \\
\left(\mathrm{mg} \mathrm{L}^{-1}\right)\end{array}$ & $\begin{array}{l}\mathrm{N}-\mathrm{NH}_{4} \\
\left(\mu \mathrm{g} \mathrm{L}^{-1}\right)\end{array}$ & $\begin{array}{c}\mathrm{P}^{\mathrm{P} \mathrm{PO}_{4}} \\
\left.\mu \mathrm{g} \mathrm{L}^{-1}\right)\end{array}$ & $\begin{array}{c}\mathrm{N} / \mathrm{P} \\
\left(\mathrm{mol} \mathrm{mol}^{-1}\right)\end{array}$ & $\begin{array}{c}\mathrm{Cl} \\
\left(\mathrm{mg} \mathrm{L}^{-1}\right)\end{array}$ & $\begin{array}{c}\mathrm{SO}_{4} \\
\left(\mathrm{mg} \mathrm{L}^{-1}\right)\end{array}$ & $\begin{array}{c}\mathrm{Ca} \\
\left(\mathrm{mg} \mathrm{L}^{-1}\right)\end{array}$ & $\begin{array}{c}\mathrm{Mg} \\
\left(\mathrm{mg} \mathrm{L}^{-1}\right)\end{array}$ & $\begin{array}{c}\mathrm{Na} \\
\left(\mathrm{mg} \mathrm{L}^{-1}\right)\end{array}$ & $\begin{array}{c}\mathrm{K} \\
\left(\mathrm{mg} \mathrm{L}^{-1}\right)\end{array}$ \\
\hline \multirow{4}{*}{ CMRo } & mean & 8.23 & 2.03 & 436 & 13.39 & 3.26 & 17.11 & 1.57 & 8343 & 6.30 & 11.92 & 80.53 & 5.02 & 2.80 & 2.54 \\
\hline & SD & 0.14 & 0.07 & 15 & 2.72 & 0.13 & 6.51 & 1.23 & 7958 & 3.99 & 0.30 & 3.40 & 0.12 & 0.79 & 3.70 \\
\hline & $\min$ & 8.11 & 1.97 & 420 & 9.13 & 3.05 & 7.78 & 0.33 & 2085 & 4.10 & 11.60 & 77.64 & 4.85 & 2.20 & 0.73 \\
\hline & $\max$ & 8.45 & 2.15 & 451 & 15.22 & 3.36 & 23.33 & 3.59 & 22099 & 13.40 & 12.40 & 86.39 & 5.13 & 4.15 & 9.15 \\
\hline \multirow[t]{4}{*}{ ССВ } & mean & 8.32 & 1.72 & 431 & 12.17 & 2.51 & 10.42 & 5.42 & 1088 & 24.40 & 13.40 & 64.77 & 6.28 & 5.92 & 16.81 \\
\hline & SD & 0.04 & 0.18 & 26 & 4.81 & 0.25 & 6.59 & 1.90 & 188 & 5.29 & 0.32 & 6.07 & 3.62 & 2.61 & 3.87 \\
\hline & $\min$ & 8.27 & 1.56 & 402 & 6.09 & 2.38 & 3.11 & 4.57 & 752 & 17.40 & 13.00 & 59.87 & 3.51 & 4.48 & 10.50 \\
\hline & $\max$ & 8.37 & 1.96 & 470 & 18.26 & 2.96 & 18.67 & 8.81 & 1188 & 31.25 & 13.71 & 74.50 & 12.61 & 10.58 & 19.99 \\
\hline
\end{tabular}


A multivariate analysis of water chemistry preferences for five invasive alien aquatic macrophytes in Connecticut (USA) revealed similar preferences for M. heterophyllum and Cabomba caroliniana, much different than those preferred by M. spicatum, Najas minor or Potamogeton crispus [47]. The probability to find M. heterophyllum increased over 0.5 with a conductivity $<91 \mu \mathrm{S} \mathrm{cm}^{-1}$; other factors significantly affecting species presence were longitude, alkalinity and $\mathrm{pH}$ but not total phosphorus [47]. However, another study on invasive populations of M. heterophyllum in New Hampshire lakes showed that this species occurred mainly in large, low elevation systems with relatively high $\mathrm{pH}$, alkalinity and conductivity [48].

This is similar to the observations made in the Champagne to Bourgogne (CCB) and the Canal from the Marne to the Rhine, Western Branch (CMRo) channels in Northeast France. Here we found large infestations in sections with very high $\mathrm{pH}$ levels of on average 8.2-8.3, and high conductivity of $400-470 \mu \mathrm{S} \mathrm{cm}^{-1}$. We also observed a high availability of inorganic nitrogen (mostly as nitrate) but very low phosphate levels, leading to very high molar $\mathrm{N} / \mathrm{P}$ ratios for inorganic $\mathrm{N}$ and $\mathrm{P}$, specifically in the CMRo Channel (Table 1). Waters contained in general higher calcium but lower magnesium, chlorine and sulfate concentrations than observed in channels with $M$. heterophyllum dominance in Eastern Germany [46]. Pore water retrieved from sediment was rich in ammonium and the N:P ratio of inorganic nutrients was much lower than observed for the water column (Table 2).

Table 2. Pore water analyses in sections of two navigation channels in Northeast France, the Canal from Champagne to Bourgogne (CCB) and the Canal from the Marne to the Rhine, Western Branch (CMRo).

\begin{tabular}{|c|c|c|c|c|c|c|c|c|}
\hline Channel & $\begin{array}{c}\text { Statistical } \\
\text { Details }\end{array}$ & $\begin{array}{c}\mathrm{N}-\mathrm{NO}_{2} \\
\left(\mu \mathrm{g} \mathrm{L}^{-1}\right)\end{array}$ & $\begin{array}{c}\mathrm{N}-\mathrm{NO}_{3} \\
\left(\mathrm{mg} \mathrm{L}^{-1}\right)\end{array}$ & $\begin{array}{c}\mathrm{N}-\mathrm{NH}_{4} \\
\left(\mu \mathrm{g} \mathrm{L}^{-1}\right)\end{array}$ & $\begin{array}{c}\mathrm{P}^{-\mathrm{PO}_{4}} \\
\left(\mu \mathrm{g} \mathrm{L}^{-1}\right)\end{array}$ & $\begin{array}{c}\mathrm{N} / \mathrm{P} \\
\left(\mathrm{mol} \mathrm{mol}^{-1}\right)\end{array}$ & $\begin{array}{c}\mathrm{Cl} \\
\left(\mathrm{mg} \mathrm{L}^{-1}\right)\end{array}$ & $\begin{array}{c}\mathrm{SO}_{4} \\
\left(\mathrm{mg} \mathrm{L}^{-1}\right)\end{array}$ \\
\hline \multirow[t]{4}{*}{ CMRo } & mean & 9.13 & 45.16 & 556.11 & 12.07 & 177 & 6.28 & 9.08 \\
\hline & SD & 10.25 & 31.93 & 128.04 & 7.70 & 147 & 2.16 & 4.57 \\
\hline & $\min$ & 3.04 & 22.58 & 474.44 & 2.94 & 65 & 4.50 & 3.20 \\
\hline & $\max$ & 24.35 & 90.32 & 746.67 & 18.93 & 389 & 9.40 & 13.30 \\
\hline \multirow{4}{*}{$\mathrm{CCB}$} & mean & 7.30 & 364.45 & 239.24 & 8.03 & 225 & 8.68 & 13.08 \\
\hline & $\mathrm{SD}$ & 5.09 & 594.04 & 258.71 & 4.01 & 274 & 1.90 & 1.86 \\
\hline & $\min$ & 3.04 & 54.19 & 26.44 & 4.57 & 57 & 5.91 & 10.06 \\
\hline & $\max$ & 15.22 & 1422.58 & 688.33 & 13.38 & 710 & 10.60 & 14.88 \\
\hline
\end{tabular}

$n=4$ for CMRo, (1 site could not be sampled), $n=5$ for CCB. Samples were taken on 12 April 2019 (CMRo) and 24 April 2019 (CCB).

\subsubsection{Light and Temperature Requirements}

The temperature optima of the species are between $20-25^{\circ} \mathrm{C}$; the species exhibits a physiological optimum at 250-300 $\mu \mathrm{mol}$ photons $\mathrm{m}^{-2} \mathrm{~s}^{-1}$ and the compensation point of photosynthesis at $20-25^{\circ} \mathrm{C}$ is about $20 \mu \mathrm{mol}$ photons $\mathrm{m}^{-2} \mathrm{~s}^{-1}[49,50]$. When acclimated to low light conditions, even slightly increased irradiances of $300 \mu \mathrm{mol}$ photons $\mathrm{m}^{-2} \mathrm{~s}^{-1}$ lead to damaging of the photosynthetic apparatus as indicated by decreasing $\mathrm{Fv} / \mathrm{Fm}$ ratios [51].

Most of the reported sites with large infestations of $M$. heterophyllum are found in water up to $1.5 \mathrm{~m}$ deep, but at some sites, plants were recorded down to 2.5 or $6 \mathrm{~m}$. Depending on the turbidity of the water, plants will easily find light intensities around their physiological optimum when growing in the upper water levels. Reddish upper shoot sections might be indicative of high anthocyanin contents, which should protect against high (UV)-irradiance [52], but other possible causes are herbivory [53] or $\mathrm{CO}_{2}$ limitation (A. Hussner, personal observation). The fast expansion of submerged macrophytes in general, and M. heterophyllum in particular in navigation channels in Northeast France might be the result of enhanced water clarity linked to lower phytoplankton density. The alternative stable states of either dominance by submerged macrophytes and clear water versus phytoplankton dominance and turbid water is a well-known fact for shallow aquatic lakes, but has also been described for slow-flowing rivers $[54,55]$. Under clear water conditions, most native submerged macrophytes profit from light reaching the sediment in spring, enabling regrowth from root propagules. This scenario 
might be different for the mainly evergreen M. heterophyllum, however, since low light attenuation will allow a deeper colonization depth.

\subsubsection{Nutrient Requirements}

The main resources allowing optimal growth for submerged macrophytes are light, carbon $\left(\mathrm{CO}_{2}\right.$, $\mathrm{HCO}_{3}{ }^{-}$), nitrogen, and phosphorus availability. Myriophyllum heterophyllum prefers mesotrophic conditions but was found under varying nutrient conditions, from oligotrophic to eutrophic (from $\sim 0.3$ up to $\sim 3 \mathrm{mg} \mathrm{L}^{-1} \mathrm{NO}_{3}-\mathrm{N}$; [46,56]). In mesotrophic urban lakes in Düsseldorf (total phosphorus (TP) 30-40 $\mu \mathrm{g} \mathrm{L}^{-1}$ ) with high sediment nutrients (between 0.37-0.49 $\mathrm{mg} \mathrm{g}^{-1} \mathrm{P}_{2} \mathrm{O}_{5}-\mathrm{TP}$ in soil), the species showed biomass densities of $330-342 \mathrm{~g} \mathrm{~m}^{-2}$ (roots and shoots contributed $13 \%$ and $87 \%$ to the biomass, respectively [49]).

Nitrogen (N) content in tissue was strongly linked to biomass in East German channels [46]. Leaf nitrogen content can depend on available $\mathrm{N}$ sources such as nitrate or ammonium if other conditions such as sufficient light and carbon (C) availability are met. In all plants, the carbon and nitrogen metabolism is strongly linked via the so-called GOGAT pathway [57]. A laboratory experiment showed by crossing two levels of $\mathrm{CO}_{2}$ availability (low and high- $\mathrm{LC}$ and $\mathrm{HC}$, respectively) with five levels of $\mathrm{NO}_{3}-\mathrm{N}$ availability at a rather low photon flux density of about $60 \mu \mathrm{mol}$ photons $\mathrm{m}^{-2} \mathrm{~s}^{-1}$ that the increase of leaf (and root) $\mathrm{N}$ with available $\mathrm{N}$ was true only under $\mathrm{HC}$, and that under LC, leaf $\mathrm{N}$ content was more or less constant at $2.5 \%-3 \%$ based on dry mass [58].

In the channels CMRo and CCB, the species exhibited C:N:P molar ratios of 613:53:1 and 567:48:1, respectively (Table 3). While the C:P molar ratios are similar to other published studies $[59,60]$ (but see that some studies use mass ratios), the N:P ratio is high and the $\mathrm{C}: \mathrm{N}$ ratio is rather low, due to the very high nitrogen content in the samples. Although it is not easy to make a direct link between $\mathrm{N}$ and $\mathrm{P}$ availability and content in plant tissue [60], we consider that the tissue nutrient concentrations is reflecting the rather low $\mathrm{P}$ but very high $\mathrm{N}$ availability particularly in the water column (Table 1 , Table 3). The dry matter content (DMC) values are a bit higher in the CMRo, and slightly lower in the CCB than found by in Eastern German channels with values of about $8 \%$ [46]. In another study, the species exhibited a rather high decomposition rate of 0.023 day $^{-1}$, measured in plants containing $36.8 \%$ carbon, $1.62 \% \mathrm{~N}$ and $0.14 \% \mathrm{P}$, yielding a molar C:N:P ratio of approx. 577:26:1 [59].

Table 3. Leaf stoichiometry and leaf dry matter content $(\mathrm{DMC})$ of apical shoots $(10 \mathrm{~cm})$ taken from two stands of five sections of two navigation channels in Northeast France, the Canal from Champagne to Bourgogne (CCB) and the Canal from the Marne to the Rhine, Western Branch (CMRo).

\begin{tabular}{|c|c|c|c|c|c|c|c|c|}
\hline Channel & $\begin{array}{c}\text { Statistical } \\
\text { Details }\end{array}$ & $\begin{array}{c}\mathrm{C} \\
\left(\mathrm{mg} \mathrm{g}^{-1}\right)\end{array}$ & $\begin{array}{c}\mathrm{N} \\
\left(\mathrm{mg} \mathrm{g}^{-1}\right)\end{array}$ & $\begin{array}{c}P \\
\left(\mathrm{mg} \mathrm{g}^{-1}\right)\end{array}$ & $\begin{array}{c}\mathrm{C} / \mathrm{P} \\
\left(\mathrm{mol} \mathrm{mol}^{-1}\right)\end{array}$ & $\begin{array}{c}\mathrm{C} / \mathrm{N} \\
\left(\mathrm{mol} \mathrm{mol}^{-1}\right)\end{array}$ & $\begin{array}{c}\mathrm{N} / \mathrm{P} \\
\left(\mathrm{mol} \mathrm{mol}^{-1}\right)\end{array}$ & $\begin{array}{c}\text { DMC } \\
(\%)\end{array}$ \\
\hline \multirow[t]{3}{*}{ CMRo } & mean & 376.70 & 38.40 & 1.66 & 612.59 & 11.65 & 52.67 & 10.12 \\
\hline & $\min$ & 324.70 & 31.30 & 1.17 & 430.64 & 8.48 & 33.47 & 6.86 \\
\hline & $\max$ & 432.00 & 55.50 & 2.24 & 841.53 & 13.17 & 69.72 & 17.83 \\
\hline \multirow[t]{3}{*}{ CCB } & mean & 374.55 & 38.00 & 1.98 & 566.58 & 11.72 & 47.65 & 7.37 \\
\hline & $\min$ & 324.60 & 29.80 & 1.09 & 255.47 & 8.90 & 22.12 & 5.81 \\
\hline & $\max$ & 408.80 & 52.30 & 3.72 & 935.67 & 15.36 & 69.25 & 10.45 \\
\hline
\end{tabular}

$n=10$ for all. Data based on the dry mass of samples. Samples were taken on 12 April 2019 (CMRo) and 24 April 2019 (CCB).

Carbon dioxide is the preferred carbon source of M. heterophyllum for photosynthesis and thus the species is usually found in water with a $\mathrm{pH}$ of 4.1-7.5 [46,56]. Various laboratory studies have investigated the impact of carbon and nutrient availability on the growth and stoichiometry of this and related species. A comparison of eight different Myriophyllum species revealed that $M$. heterophyllum had among the highest relative growth rates (RGR) when cultivated in nutrient-rich sediment under high $\mathrm{CO}_{2}$ availability [61]. The chlorophyll content decreased with increasing $\mathrm{CO}_{2}$ availability, and 
was negatively correlated with increasing leaf starch content and root mass fraction [61]. However, another study showed that these effects of increasing $\mathrm{CO}_{2}$ availability were strongly pronounced at low water nutrients of $0.1-0.5 \mathrm{mg} \mathrm{L}^{-1}$ of $\mathrm{NO}_{3}-\mathrm{N}$, but were absent at high nutrients of $4 \mathrm{mg} \mathrm{L}^{-1}$ of $\mathrm{NO}_{3}-\mathrm{N}[58]$.

In addition to $\mathrm{CO}_{2}, M$. heterophyllum can use $\mathrm{HCO}_{3}{ }^{-}$as an inorganic carbon source although M. spicatum has a better $\mathrm{HCO}_{3}{ }^{-}$use capacity [50]. Pulse-chase experiments in the 1980s showed that M. heterophyllum, similar to other macrophytes, uses also PEP-carboxylase for photosynthesis [62]. The species may be increasing its ecological niche by colonizing systems with $\mathrm{HCO}_{3}{ }^{-}$dominance, as observed recently in Northeast France, where it was found at pH values of about 8.0-8.5 (Table 1), implying a dominant use of $\mathrm{HCO}_{3}{ }^{-}$. This would be coherent with observations in New Hampshire [48] finding this species in high $\mathrm{pH}$ and alkalinity systems. In fact, lineages growing at higher alkalinity had a higher individual plant biomass, and a higher $\mathrm{pH}$ resulted in a higher overall biomass of the stands [38].

We observed total chlorophyll contents of $11-12 \mathrm{mg} \mathrm{g}^{-1}$ dry weight, with a ratio between chl a and $b$ of about 2.5-3.5 in apical leaves taken from two channels in Northeast France (Table 4 ). These are similar to values reported in [46] of about $10-13 \mathrm{mg} \mathrm{g}^{-1}$, and $\mathrm{chl} \mathrm{a} / \mathrm{b}$ ratios of 3-3.5. Both $\mathrm{N}^{-}$and $\mathrm{CO}_{2}$ availability can influence the chlorophyll content of this plant, but a higher total chlorophyll content with increasing $\mathrm{N}$ availability was only observed under HC [58]. The content in phenolic compounds was on average almost twice as high in CCB than in CMRo (Table 4), but lower than observed for M. spicatum middle leaves from Lake Constance, Germany [63].

Table 4. Leaf pigment content (chlorophyll a, b, total chlorophyll, ratio a/b; carotenoids (car)), content in anthocyanins (Acy) and total phenolic compounds (TPC) of apical shoots $(10 \mathrm{~cm})$ taken from two stands of five sections of two navigation channels in Northeast France, the Canal from Champagne to Bourgogne (CCB) and the Canal from the Marne to the Rhine, Western Branch (CMRo).

\begin{tabular}{|c|c|c|c|c|c|c|c|c|}
\hline Channel & $\begin{array}{c}\text { Statistical } \\
\text { Details }\end{array}$ & $\begin{array}{c}\text { Chl a } \\
\left(\mathrm{mg} \mathrm{g}^{-1}\right)\end{array}$ & $\begin{array}{c}\text { Chl b } \\
\left(\mathrm{mg} \mathrm{g}^{-1}\right)\end{array}$ & $\begin{array}{l}\text { Chl a+b } \\
\left(\mathrm{mg} \mathrm{g}^{-1}\right)\end{array}$ & $\begin{array}{c}\mathrm{Chl} \mathrm{a} / \mathrm{b} \\
\left(\mathrm{mg} \mathrm{mg}^{-1}\right)\end{array}$ & $\begin{array}{c}\text { Car } \\
\left(\mathrm{mg} \mathrm{g}^{-1}\right)\end{array}$ & $\begin{array}{c}\text { Acy } \\
\left(\mathrm{mg} \mathrm{g}^{-1}\right)\end{array}$ & $\begin{array}{c}\text { TPC } \\
\left(\mathrm{mg} \mathrm{g}^{-1}\right)\end{array}$ \\
\hline \multirow[t]{4}{*}{ CMRo } & mean & 8.09 & 2.60 & 10.69 & 3.13 & 1.46 & 0.88 & 30.83 \\
\hline & SD & 1.27 & 0.43 & 1.63 & 0.30 & 0.32 & 0.69 & 8.28 \\
\hline & $\min$ & 5.93 & 1.94 & 7.86 & 2.68 & 0.96 & 0.07 & 15.84 \\
\hline & $\max$ & 10.43 & 3.38 & 13.37 & 3.54 & 2.05 & 2.10 & 39.64 \\
\hline \multirow[t]{4}{*}{ ССВ } & mean & 8.46 & 2.89 & 11.36 & 3.03 & 1.49 & 0.76 & 59.73 \\
\hline & SD & 1.60 & 0.93 & 2.50 & 0.44 & 0.26 & 0.49 & 24.84 \\
\hline & $\min$ & 7.07 & 2.05 & 9.12 & 2.51 & 1.02 & 0.08 & 31.30 \\
\hline & $\max$ & 12.23 & 4.87 & 17.10 & 3.52 & 1.84 & 1.62 & 112.21 \\
\hline
\end{tabular}

$n=10$ for all. Data based on the dry mass of samples. Samples were taken on 12 April 2019 (CMRo) and 24 April 2019 (CCB).

\subsection{Synecology}

\subsubsection{Associated Plant Species and Competition}

Myriophyllum heterophyllum has been reported from a wide range of habitats within Europe. The species co-occurs with species such as Pilularia globulifera, Eleocharis acicularis and Juncus bulbosus in acidic lakes, and in lakes with a more neutral $\mathrm{pH}$, it was accompanied by Potamogeton lucens, Potamogeton natans or $M$. verticillatum $[46,50,64]$. A problem for management options might be that the species can be associated with rare and vulnerable native aquatic plant species, such as Luronium natans [42]. In the canals in Northeast France, we observed it associated with Elodea nuttallii, Potamogeton perfoliatus and M. spicatum.

Myriophyllum heterophyllum is reported growing in close competition with native species such as M. verticillatum [32]. The highly competitive strength of $M$. heterophyllum is most likely based on the evergreen growth of the species. Moreover, the $\mathrm{HCO}_{3}{ }^{-}$use capacity of M. heterophyllum, even though 
limited, might cause the displacement of obligate $\mathrm{CO}_{2}$ users such as M. verticillatum under high $\mathrm{pH}$ $(\mathrm{pH}>8)[61]$.

In general, there is some evidence that evergreen species show generally lower growth rates than seasonal species, but being evergreen can compensate for the lower growth rate during the main growing season $[65,66]$. Moreover, evergreen species have an advantage for their spread into new areas, as fragments dispersed into new, not vegetated areas in late autumn to early spring will not be limited in its colonization process by the biotic resistance of the habitat by native plants [67]. However, it must be borne in mind, that the likelihood of regeneration and colonization of M. heterophyllum fragments might be reduced in cold water.

Even though the benefit of being evergreen has not been studied for M. heterophyllum in detail yet, evergreen growth would allow it to colonize sites formerly dominated by seasonal species and potentially displace native vegetation. Such a case has been demonstrated for the exotic evergreen Vallisneria spiralis displacing native seasonal Sparganium emersum [65]. In Alaska, the non-native Elodea canadensis also remains evergreen under ice [68]. The aboveground persistence of $M$. heterophyllum shoots during winter and the growth already early in spring compensates well for the disadvantage of potentially lower maximum growth rates in summer compared to seasonal species such as M. spicatum [50]. This is true particularly in habitats with only moderate periods of cold winter temperatures like in the oceanic climatic zones within Europe.

\subsubsection{Herbivory}

The past 30 years have shown that even small insects can be efficient herbivores on large-scale invasions of submerged or floating macrophytes [69-71]. Several Curculionidae have been described feeding on Myriophyllum species in man-made lakes in Northern Germany; Bagous collignensis, Eubrychius velutus and Phytobius leucogaster were found on M. heterophyllum [72]. No differences in development times for eggs and larvae until the adult stage were found for E. velutus reared on four different Myriophyllum species (M. alterniflorum, M. heterophyllum, M. spicatum and M. verticillatum) [73].

The curculionid weevil Euhrychiopsis lecontei, native to North America, is considered an efficient herbivore of M. spicatum, invasive in North America [70]. This insect herbivore underwent a fast shift in host plant preference from native species, specifically M. sibiricum, towards the invasive congener [74]. The host plant preference of E. lecontei for the invasive milfoil species seems very strong, as very little herbivore damage, egg-laying or larval presence has been found on six Myriophyllum species native to (parts) of North America, including M. heterophyllum. Further details on the potential use of this and other insect herbivores as biocontrol agents are outlined below (Section 6.3). We observed frequent herbivore damage on local specimens of M. heterophyllum in Northeast France, specifically at apical parts, possibly caused by curculionids or Lepidoptera larvae (Figure 5). Even though the current damage is negligible, prior research on an aquatic moth, attacking $M$. spicatum in upstate New York has shown that herbivory can indeed be a cause of a reduction in biomass, as apical damage will prevent canopy formation and open windows to enhance the growth of native species $[75,76]$. Most of these herbivores cannot be considered as true biocontrol agents as they feed on more than one species, but they might help in long-term control of nuisance species such as the different invasive species in the genus Myriophyllum (see Section 6.3 below). It is important to know that extensive management practices such as mowing will remove potential herbivores and might prolong the presence of the nuisance species in the system [7]. 


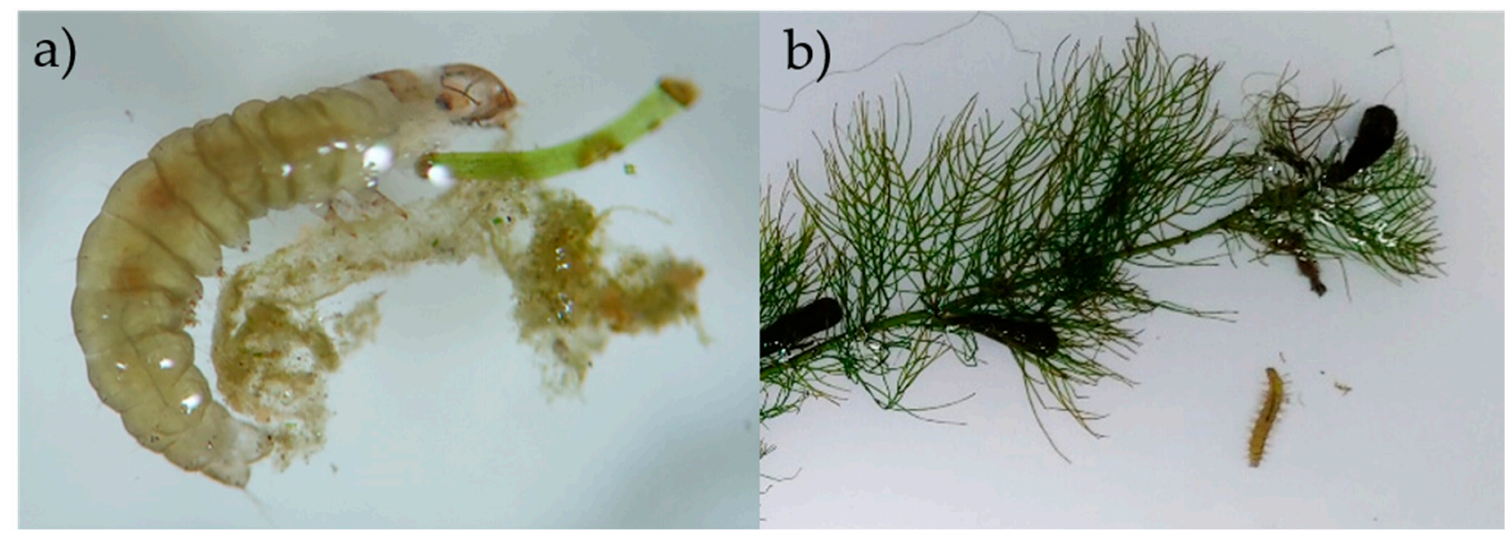

Figure 5. Aquatic insect herbivores found on Myriophyllum spp. from waterways in Northeast France. (a) Acentria ephemerella found on M. heterophyllum from the Canal between the Marne and the Rhine, Branch West. (b) Parapoynx stratiotata found on M. verticillatum from the Ardennes Canal. Both species are aquatic moth larvae and belong to the Crambidae. Photos E. Gross.

\subsubsection{Pathogens and Toxic Interactions}

For M. spicatum, an unexpected decline had been observed in Chesapeake Bay in the 1960s, initially attributed to a virus disease followed by a gram-negative bacterium, but later ascribed to abiotic factors, as summarized in [77]. To our knowledge, no pathogen-related decline has been described so far for M. heterophyllum.

Cyanotoxins are of high concern in the management of aquatic systems. A screening of the presence of three cyanotoxins (neurotoxins: BMAA/beta- $N$-methylamino-L-alanine, DABA/2.4-diaminobutryric acid dihydrochloride, anatoxin-a) in 2009 and 2010 in Nebraska reservoirs revealed that these toxins were found in more than $40 \%$ of all samples taken from three invasive Myriophyllum species (M. aquaticum, M. heterophyllum and M. spicatum) [78]. This suggests that the submerged macrophytes were colonized by cyanobacterial epiphytes containing these cyanotoxins. It is unlikely that the compounds harm the host plant, but the colonized plants themselves can have toxic effects on animals consuming the plant tissue.

\section{Environmental Factors Influencing Growth and Dispersal}

Viable seed production has not been observed so far for M. heterophyllum in its introduced range in Europe [2]. Consequently, the spread is restricted to vegetative dispersal. In general, plants can regenerate from small shoot fragments $(<1 \mathrm{~cm})$ or even single leaves [49], but regeneration rates are much lower and require a longer time than observed for other submerged plants like M. spicatum, Elodea canadensis or Hydrilla verticillata $[79,80]$.

Similar to other aquatic plants, shoot fragments are produced via autofragmentation (self-induced fragmentation) and/or allofragmentation (fragmentation caused by physical disturbance). The number of shoot fragments produced by M. heterophyllum is rather low; however, $\sim 60 \%$ of the produced fragments already possess roots (E. Gross, own observations; [45]). Shoot fragments are transported within connected water systems by drift. The drift distance of aquatic plant fragments is largely determined by their buoyancy and water body characteristic fragment retention patterns (such as existing vegetation, stones, overhanging trees) (A. Hussner, P. Heidbüchel, personal communication).

In contrast to the dispersal within connected water bodies, the overland transport into not connected water bodies seems mainly due to human-mediated spread, and particularly water sports equipment used for recreational fishing, boating or other activities, can be a major vector [81]. Waterfowl often transport seeds of aquatic plants [82], and are thus a potential vector for the transport of alien invasive plants. However, since viable seeds are seemingly not present in Europe, and the size of 
viable plant fragments is larger than, e.g., Lemna fronds [83], waterfowl seem unlikely to be involved in the propagation of M. heterophyllum.

However, the likelihood of overland dispersal of M. heterophyllum fragments is strongly influenced by the proven high tolerance against desiccation [84]. Even $\sim 80 \%$ of water loss did not result in a general die-off, and fragments were still able to regenerate [85]. This would indicate that either rooted plants, or loose fragments drying off might have a chance to regrow. Clumped plant fragments, as often found attached to boats or trailers, maintain humidity much longer and thus remain viable for a considerable time. This mechanism can be a major vector for the overland dispersal of fragments [86].

\section{Regulation and Control Measures}

\subsection{Regulatory Demands and Challenges to Overcome}

Given the described negative effects of $M$. heterophyllum in invaded areas, it is not surprising to find it on the EU list of species for the prevention and management of invasive alien species $[4,5]$. In the following, we will outline details of this EU regulation [4], highlighting key terms used in the respective articles of the regulation in italics. This regulation and its amendment recognize that dedicated measures applicable across the Union should be adopted if the species is causing significant damage in Member States (Article 10). First, a detailed risk assessment needs to be made (Article 11). Such a risk assessment was provided shortly after the regulation became effective [2]. A crucial action to be taken is to manage the pathways of unintentional introduction (Article 21), but it is considered that this should include voluntary measures and be based on prior experiences. As described earlier (Section 2), maintaining (an) adequate and actual database(s) on the distribution of an invasive alien species is not an easy task. The regulation explicitly asks for research, monitoring and surveillance of such species. This requires that targeted and general surveys should be taken and that different sectors and stakeholders, including regional and local communities, should be involved (Article 22). Our experience with the fast spread of M. heterophyllum in Northeast France shows the importance of information flow. The local and regional contact persons for new observations should be easily accessible, and the transfer of new observation sites should follow a standardized procedure. Early detection and rapid eradication measures are essential as outlined in (Article 24), but this is often hampered by the clear identification of invasive alien species, such as outlined above for M. heterophyllum (Section 3). A centralized information system should collate existing information (Article 28). The European Alien Species Information Network EASIN [87] lists M. heterophyllum, but not all locations outlined above (Section 2) are included in the maps provided. The transfer of information from local and regional stakeholders and databases should, therefore, be revised and improved, not only to collate all available information, but also to alert neighbor countries about the potential risk. A recent study shows that the biosecurity of a given country influences that of its neighbors [88]; the authors requested stronger regional biosecurity to prevent future harmful biological invasions and asked for stronger regional cooperation. Given the lack of detailed information, as outlined above (Section 2), national and European legislation should develop mandatory actions to stop the further spread of M. heterophyllum.

If the species has established, the management measures should avoid any adverse impact on the environment or human health (Article 25). However, often eradication programs for submerged invasive alien macrophytes are initiated without a clear evaluation of the risks and benefits for the ecosystem. Observations show that harvested biomass contains not only the targeted plant, but also other aquatic plant species and many associated animals, such as macroinvertebrates (insect larvae, snails, crayfish) or fish. Invasive alien species reduce the resilience of affected ecosystems. Therefore, proportionate restoration measures should be undertaken (Article 26). These include strengthening the ecosystems' resilience towards invasions, to repair the damage caused and to enhance the conservation status of species and habitats in concordance with the Habitats Directive (92/43/EEC), the Birds Directive (2009/147/EC), and the ecological status of aquatic systems in concordance with the Water Framework Directive (2000/60/EC). Ideally, eradication measures should already take into account effects on the ecosystem and foresee 
necessary restoration measures to avoid negative effects, such as the complete loss of submerged macrophytes [89]. The costs of restoration measures should be recovered in accordance with the polluter pays principle (Article 26), but this should in most cases be impossible to put into force as entranceways for submerged invasive alien macrophytes can be multiple and are difficult to relate to a single cause.

This new EU regulation [4] is a first step targeting the worst invasive alien species in the European Union, but its practicability and implementation have to be monitored carefully in the next few years.

\subsection{Mechanical Control}

Harvesting submerged invasive alien macrophytes is a widespread practice, and various techniques are applied to cut or uproot the targeted species [89]. Several problems are linked to this approach, as it is almost impossible to retain all plant fragments, and subsequent spread of the species might even be stronger. Management practices such as annual mowing sessions can even sustain an invasive alien population for a longer time than without intervention, possibly due to the removal of herbivores and/or release from density suppression [7,69]. If the harvested material is kept close to the shoreline, nutrient-rich leachates will cause strong eutrophication of the system that might stimulate either further growth of the invasive alien species or cause massive algal blooms.

Appropriate mechanical control of M. heterophyllum includes techniques such as 'hydro-venturi' or the 'harkboat' (A. Hussner, R. Pots, J. van Valkenburg, personal communication), both aiming to uproot the plants and remove the biomass as much as possible from the system. The timing of the harvest should be late in the fall to protect native macrophytes and remove the competitive advantage of the evergreen M. heterophyllum. Details on applied strategies and success controls can be found in $[2,89]$.

\subsection{Biological Control}

Using natural enemies present in the native range of invasive alien plant species is an accepted control technique. To avoid any risk for native species in the invaded range, such natural enemies need to be highly host-specific and bear no risk to shift host preference over time. Many biological control agents have stronger side effects than initially anticipated, and thus, although potentially effective against the nuisance species, might not be ecologically safe [90].

The most widespread biological control agents are herbivores and pathogens. Herbivores that are potential or documented biological control agents against nuisance aquatic plants can be adults or larvae of aquatic insects, and most of them belong only to few families within Lepidoptera (Noctuidae, Pyralidae) or Coleoptera (Chrysomelidae, Curculionidae) [71]. Pathogens can be either bacteria, fungi or viruses, but most promising so far have been fungi [91]. Details on potential herbivores and pathogens susceptible to interact with $M$. heterophyllum or related species have been presented before (Sections 4.1.2 and 4.1.3). Not all of the herbivores are specialized herbivores, i.e., feeding on only one species (or genus), and are thus not suitable for biological control. Almost nothing is known about potential biocontrol agents for $M$. heterophyllum, and conclusions can only be drawn by extrapolating from published studies on congeneric species such as M. aquaticum or M. spicatum [70,71,92,93].

However, despite several field releases of E. lecontei in the Northeast of the USA, significant reductions of $M$. spicatum were low or not long-lasting [94]. Different reasons might account for this. One is fish predation or mechanical harvesting, which both can interfere with the permanent establishment of the weevils on milfoil in the treated lakes [95,96]. Another study recommends the combined treatment of weevil stocking and herbicide application [97], however, herbicide treatment can also negatively affect weevil densities [98]. In Europe, the effect of native herbivores on M. heterophyllum should receive more attention. The European milfoil weevil E. velutus could be a suitable target organism, as it is highly specific to Myriophyllum species [72,73].

Triploid grass carp are often used as biocontrol of nuisance, submerged macrophytes. When offered alone or in combination with the benthic cyanobacterium Lyngbia wollei, grass carp fed on M. heterophyllum [99]. However, they avoided the congener M. spicatum and preferred feeding on 
other submerged macrophytes [100], maybe due to the high phenolic content of this species [63]. If the same would be true for $M$. heterophyllum, the use of grass carp could even enhance the dominance of this species. Several bacterial and fungal pathogens have been tested against nuisance aquatic weeds $[91,92,101]$. To our knowledge, no such tests have been done so far specifically for M. heterophyllum. Fungal strains of Mycoleptodiscus terrestris were pathogenic and phytotoxic to M. spicatum, and showed also pathogenic effects on M. aquaticum, but only in laboratory tests and mesocosms [102]. A field application of pathogens has never been shown.

\subsection{Chemical Control}

The control of invasive aquatic species with herbicides is not allowed in the European Union, but is common practice in North America and Oceania. A wide range of herbicides is allowed in the USA for use in aquatic systems against invasive alien aquatic species, but the challenge is to find appropriate and species-specific control [103]. In general, Myriophyllum species are fast-growing, canopy-forming species, where the phytohormone auxin enhances the growth of the main shoot. In consequence, herbicides that are auxin-analogs are the first choice to control the species. Different formulas of 2,4-D (2,4-dichlorophenoxy acetic acid) were applied on stands of M. heterophyllum in Connecticut, USA [46], but with limited success and mainly on stands in shallow water. A new synthetic auxin (florpyrauxifen-benzyl), approved by the United States Environmental Protection Agency (US EPA), has been tested in large mesocosm experiments against M. spicatum, hybrid Eurasian watermilfoil (M. spicatum $\times$ M. sibiricum) and seven native submerged macrophytes [104]. The authors concluded that native macrophytes showed the lowest sensitivity, and that the hybrid milfoil was less sensitive than $M$. spicatum. An earlier study showed that hybrid Eurasian watermilfoil was less sensitive to auxinic herbicides (2,4-D and triclopyr) [105]. So-called 'protox' inhibitors blocking chlorophyll synthesis and resulting in the formation of oxygen radicals that will cause electron leakage showed a significant effect on several submerged macrophytes, but only at elevated concentrations for M. heterophyllum [106]. Some studies combined the use of a fungal pathogen (e.g., M. terrestris) with herbicides and found enhanced negative (synergistic) effects on the performance of M. spicatum [101]. Based on these different studies we conclude that herbicide treatments are possible, but not without risk, as M. heterophyllum or its hybrid are often not among the most sensitive species.

\subsection{Prevention of Spread}

In general, the ornamental plant trade is a major pathway of the introduction of invasive alien aquatic plants into Europe, but $M$. heterophyllum had not been found in trade in a comprehensive study of aquatic plants in trade in Germany [107]. However, it seems likely that the species is traded under incorrect names or synonyms like in the Netherland, where the species is reported to be sold under misapplied names [108]. Consequently, the efficiency of any trading ban (as requested by the EU Regulation 1143/2014 [4]) or agreement to ban the species from sale depends on effective species identification tools for imported and traded plant species. DNA barcoding is a new valuable tool to distinguish M. heterophyllum from other Myriophyllum species [109].

Most invasions by invasive alien aquatic plant species occur at sites of public access, such as harbors, boat launches, angling or swimming sites. Moreover, water sports equipment can be a major vector for the overland transport of invasive alien aquatic plant fragments into new water bodies [81,110,111]. Accidental or intentional introductions can further result from release from aquaria or escape from cultivating ponds [112]. Public awareness campaigns and citizen science projects about invasive alien aquatic plants are valuable tools to reduce the likelihood of unintentional spread. The "Stop Aquatic Hitchhikers" and "Clean, Check and Dry" campaigns are two examples of such public awareness campaigns, which were initiated in the US, New Zealand, the UK and Canada [113-116]. In addition, several control strategies might reduce the likelihood for the transport of vital plant fragments, like weed-free haul-out areas at the sites of entry and release of boats, the thorough collection of viable plant fragments from trailered boats or boat washing or heating stations to kill plant parts [2,117]. The 
difficulty is that voluntary control of boats and vessels will not result in comprehensive protection of water bodies for the unintended introduction of a target species, and thus also mandatory regulations are required.

Early detection warnings could benefit from citizen science involvement, such as put into place in Maine (USA) or Quebec (Canada) [118,119]. However, a close follow-up by professionals is needed to confirm the identity of the species in question, particularly when there is a risk for misidentification. It seems important to inform and advise the broad public about the risks and impact of invasive alien species such as M. heterophyllum, so that they understand the request to prevent its spread, but also would be willing to help to survey its appearance in new places.

\section{Conclusions}

The EU has rightly placed $M$. heterophyllum on the list of highly dangerous alien invasive species. In several countries in Europe and some states of the USA, the species is of high concern due to its very fast spread resulting in high environmental and socioeconomic costs. With this comprehensive review, we aim to highlight environmental conditions and plant traits that add to the high invasiveness of the species. We suggest that future risk assessment should take into account the physiological amplitude of this species, to identify future sites of invasion. Large infestations are almost impossible to eradicate and only difficult to control in magnitude. It is thus very important to enhance the recognition of the species, to install early warning systems, e.g., by participative science to prevent further negative effects and to implement mandatory actions stopping the further spread of the species.

Author Contributions: Individual contributions are as follows: conceptualization, E.M.G. and A.H.; methodology, E.M.G. and A.H.; investigation, E.M.G., H.G. and C.P.; data curation, E.M.G., H.G. and C.P.; writing-original draft preparation, E.M.G. and A.H.; writing-review and editing, E.M.G., H.G., C.P. and A.H.; visualization, E.M.G., H.G., C.P. and A.H.; funding acquisition, E.M.G. and C.P. All authors have read and agreed to the published version of the manuscript.

Funding: This research was in part funded by a contract with VNF, DT Nancy and by local funding of the host laboratory of E.M.G.

Acknowledgments: We greatly appreciate information obtained on the local spread of the species and environmental conditions by Jonathan Newman, Trevor Renals, Max Wade (UK), J. van Valkenburg, R. Pot (NL), Nina Vuković (Croatia), Sara Calero (Spain), Donald Les (CT, USA), Zoltán Barina (Hungary), and Nathalie Dubost (France). We thank P. Rousselle, V. Goncalvez, D. Pauly and M. Beuret for help with water and plant analyses.

Conflicts of Interest: The authors declare no conflict of interest. The funders had no role in the design of the study; in the collection, analyses, or interpretation of data; in the writing of the manuscript, or in the decision to publish the results.

\section{References}

1. Hussner, A. Alien aquatic plant species in European countries. Weed Res. 2012, 52, 297-306. [CrossRef]

2. Anderson, L.; Fried, G.; Gunasekera, L.; Hussner, A.; Newman, J.; Starfinger, U.; Stiers, I.; van Valkenburg, J.; Tanner, R. Pest Risk Analysis for Myriophyllum Heterophyllum; European and Mediterranean Plant Protection Organization (EPPO): Paris, France, 2015; p. 32.

3. EPPO. EPPO List of Invasive Alien Plants. Available online: https://www.eppo.int/ACTIVITIES/invasive_ alien_plants/iap_lists (accessed on 17 January 2020).

4. EU. Regulation (EU) No 1143/2014 of the European Parliament and of the Council of 22 October 2014 on the Prevention and Management of the Introduction and Spread of Invasive Alien Species. Available online: https: //eur-lex.europa.eu/legal-content/EN/TXT/?uri=OJ:JOL_2014_317_R_0003 (accessed on 4 November 2019).

5. EU. Commission Implementing Regulation (EU) 2017/1263 of 12 July 2017 Updating the List of Invasive Alien Species of Union Concern Established by Implementing Regulation (EU) 2016/1141 Pursuant to Regulation (EU) No 1143/2014 of the European Parliament and of the Council. Available online: https: //op.europa.eu/en/publication-detail/-/publication/7ca17aa9-6788-11e7-b2f2-01aa75ed71a1 (accessed on 12 November 2019).

6. Aiken, S.G. A conspectus of Myriophyllum (Haloragaceae) in North America. Brittonia 1981, 33, 57-69. [CrossRef] 
7. Chambers, P.A.; Barko, J.W.; Smith, C.S. Evaluation of invasions and declines of submersed aquatic macrophytes. J. Aquat. Plant Manag. 1993, 31, 218-220.

8. Thum, R.A.; Zuellig, M.P.; Johnson, R.L.; Moody, M.L.; Vossbrinck, C. Molecular markers reconstruct the invasion history of variable leaf watermilfoil (Myriophyllum heterophyllum) and distinguish it from closely related species. Biol. Invasions 2011, 13, 1687-1709. [CrossRef]

9. Les, D.H.; Mehrhoff, L.J. Introduction of nonindigenous aquatic vascular plants in Southern New England: A historical perspective. Biol. Invasions 1999, 1, 281-300. [CrossRef]

10. Variable-Leaf Milfoil-Myriophyllum heterophyllum. Available online: https:/www.nwcb.wa.gov/weeds/ variable-leaf-milfoil (accessed on 12 January 2020).

11. Canadensys: Myriophyllum heterophyllum. Available online: http://data.canadensys.net/vascan/taxon/6097? lang=en (accessed on 21 February 2020).

12. Lebreton, A. Myriophyllum heterophyllum Michaux [Haloragaceae] en Haute-Vienne (Limousin, France), et situation de cette plante invasive en France et en Europe. EPPO Bull. 2013, 43, 180-192. [CrossRef]

13. GBIF: Myriophyllum heterophyllum Michaux. Available online: https://www.gbif.org/species/100027408 (accessed on 21 February 2020).

14. Tropicos: Myriophyllum heterophyllum. Available online: https://www.tropicos.org/nameSearch?name= myriophyllum\%20heterophyllum (accessed on 21 February 2020).

15. Yu, D.; Wang, D.; Li, Z.Y.; Funston, A.M. Taxonomic revision of the genus Myriophyllum (Haloragaceae) in China. Rhodora 2002, 104, 396-421.

16. Jasprica, N.; Lasić, A.; Hafner, D.; Bratoš Cetinić, A. European invasion in progress: Myriophyllum heterophyllum Michx. (Haloragaceae) in Croatia. Nat. Croat. 2017, 26, 99-103. [CrossRef]

17. Wimmer, W. Myriophyllum heterophyllum Michaux in Lower Saxony and Bremen and determination key for the vegetative stage. Florist. Rundbr. 1997, 31, 23-31.

18. Myriophyllum heterophyllum - Verschiedenblättriges Tausendblatt. Available online: https://www.neobiotaaustria.at/ms/neobiota-austria/neobiota_recht/neobiota_steckbriefe/tausendblatt/ (accessed on 12 January 2020).

19. Myriophyllum heterophyllum Michx.-CH. Available online: https://www.infoflora.ch/de/flora/myriophyllumheterophyllum.html. (accessed on 18 February 2020).

20. Lukács, B.A.; Mesterházy, A.; Vidéki, R.; Király, G. Alien aquatic vascular plants in Hungary (Pannonian ecoregion): Historical aspects, data set and trends. Plant Biosyst. 2016, 150, 388-395. [CrossRef]

21. Barina, Z. Flora of the Gerecse Mountains; Magyar Természettudományi Múzeum \& Duna-Ipoly Nemzeti Park Igazgatóság: Budapest, Hungary, 2006; pp. 1-612.

22. Cartografía y Medidas Para la Eliminación de Myriophyllum heterophyllum Michx. en Los Pozos de La Arboleda (Trapagaran, Bizkaia). Available online: https://www.researchgate.net/publication/331225278_ Cartografia_y_medidas_para_la_eliminacion_de_Myriophyllum_heterophyllum_Michx_en_los_pozos_ de_La_Arboleda_Trapagaran_Bizkaia (accessed on 23 March 2020).

23. Cirujano, S.; Medina, L.; Stübing, G.; Peris, J.B. Myriophyllum heterophyllum Michx. (Haloragaceae), naturalized in Spain. An. Jard. Bot. Madr. 1997, 55, 164-165.

24. Servei de Vida Silvestre. Actuaciones de Control de Especies Invasoras. In Informe Técnico 04/2018: Technical Report from Direcció General de Medi Natural i d'Avaluació Ambiental; Memoria Anual 2017; Generalitat Valenciana: Valencia, Spain, 2018.

25. De Beer, D.; De Vlaeminck, R. Myriophyllum heterophyllum, een nieuwe invasieve waterplant (English: A new invasive aquatic plant). Dumortiera 2008, 94, 8-13.

26. Myriophyllum heterophyllum. Available online: https://waarnemingen.be/species/17153/ (accessed on 14 March 2020).

27. EPPO. Myriophyllum heterophyllum Michaux. EPPO Bull. 2016, 46, 20-24. [CrossRef]

28. Myriophyllum heterophyllum Michx.-NL. Available online: https://www.verspreidingsatlas.nl/5500 (accessed on 18 February 2020).

29. Peeters, G.M.T. Een vreemd vederkruid in het Zwartwater (English: An unusual water-milfoil at the Zwartwater pond): Myriophyllum heterophyllum Michx. Nat. Hist. Maandbl. 2004, 93, 251-252.

30. Myriophyllum heterophyllum-Q-Bank. Available online: https://-bankplants.eu/Biolomics.aspx?Table= Plants\%20-\%20Specimens (accessed on 18 February 2020). 
31. FloraWeb. Verbreitung der Farn- und Blütenpflanzen in Deutschland; Aggregiert im Raster der Topographischen Karte 1:25000. Datenstand 2013/Verbreitungsatlas. Available online: http://www.floraweb.de (accessed on 12 January 2020).

32. Hussner, A.; Nienhaus, I.; Krause, T. Zur Verbreitung von Myriophyllum heterophyllum Michx. in Nordrhein-Westfalen. Flor. Rundbr. 2005, 39, 113-120.

33. Myriophyllum heterophyllum-FR. Available online: http://especes-exotiques-envahissantes.fr/espece/ myriophyllum-heterophyllum/ (accessed on 12 January 2020).

34. Saint-Val, M. Myriophyllum heterophyllum. 2019. Available online: http://cbnbp.mnhn.fr/cbnbp/ressources/ alaloupe/Myriophyllum_heterophyllum_Mathieu_Saint-Val.pdf (accessed on 11 March 2020).

35. Moody, M.L.; Les, D.H. Systematics of the aquatic angiosperm genus Myriophyllum (Haloragaceae). Syst. Bot. 2010, 35, 121-139. [CrossRef]

36. Thum, R.A.; Lennon, J.T.; Connor, J.; Smagula, A.P. A DNA fingerprinting approach for distinguishing native and non-native milfoils. Lake Reserv. Manag. 2006, 22, 1-6. [CrossRef]

37. Moody, M.L.; Les, D.H. Evidence of hybridity in invasive watermilfoil (Myriophyllum) populations. Proc. Natl. Acad. Sci. USA 2002, 99, 14867-14871. [CrossRef]

38. Tavalire, H.F.; Bugbee, G.E.; LaRue, E.A.; Thum, R.A. Hybridization, cryptic diversity, and invasiveness in introduced variable-leaf watermilfoil. Evol. Appl. 2012, 5, 892-900. [CrossRef]

39. Thum, R.A.; Lennon, J.T. Is hybridization responsible for invasive growth of non-indigenous water-milfoils? Biol. Invasions 2006, 8, 1061-1066. [CrossRef]

40. Environmental Fact Sheet-Variable Watermilfoil Myriophyllum heterophyllum. 2019. Available online: https://www.des.nh.gov/organization/commissioner/pip/factsheets/bb/documents/bb-23.pdf (accessed on 12 January 2020).

41. GISD. Species Profile Myriophyllum heterophyllum. 2015. Available online: http://www.iucngisd.org/gisd/ species.php?sc=1700 (accessed on 17 February 2020).

42. Myriophyllum heterophyllum. Available online: http://alienplantsbelgium.be/content/myriophyllumheterophyllum (accessed on 12 January 2020).

43. Sculthorpe, C.D. The Biology of Aquatic Vascular Plants; Edward Arnold Publishers: London, UK, 1967; pp. 1-610.

44. Zepeda, C.G.; Lot, A.; Antonio Nemiga, X.; Manjarrez, J. Seed bank and established vegetation in the last remnants of the Mexican Central Plateau wetlands: The Lerma marshes. Rev. Biol. Trop. 2014, 62, 455-472. [CrossRef] [PubMed]

45. Heidbuechel, P.; Sachs, M.; Stanik, N.; Hussner, A. Species-specific fragmentation rate and colonization potential partly explain the successful spread of aquatic plants in lowland streams. Hydrobiologia 2019, 843, 107-123. [CrossRef]

46. Pietsch, W.; Jentsch, H. Zur Soziologie und Ökologie von Myriophyllum heterophyllum Mich. in Mitteleuropa. Gleditschia 1984, 12, 303-335.

47. June-Wells, M.; Gallagher, F.; Gibbons, J.; Bugbee, G. Water chemistry preferences of five nonnative aquatic macrophyte species in Connecticut: A preliminary risk assessment tool. Lake Reserv. Manag. 2013, 29, 303-316. [CrossRef]

48. Thum, R.A.; Lennon, J.T. Comparative ecological niche models predict the invasive spread of variable-leaf milfoil (Myriophyllum heterophyllum) and its potential impact on closely related native species. Biol. Invasions 2010, 12, 133-143. [CrossRef]

49. Hussner, A. Ökologische und Ökophysiologische Charakteristika Aquatischer Neophyten in Nordrhein-Westfalen. Ph.D. Thesis, Biology, Heinrich-Heine University, Düsseldorf, Germany, 2008; pp. 1-192.

50. Hussner, A.; Jahns, P. European native Myriophyllum spicatum showed a higher $\mathrm{HCO}_{3}{ }^{-}$use capacity than alien invasive Myriophyllum heterophyllum. Hydrobiologia 2015, 746, 171-182. [CrossRef]

51. Hussner, A.; Hoelken, H.P.; Jahns, P. Low light acclimated submerged freshwater plants show a pronounced sensitivity to increasing irradiances. Aquat. Bot. 2010, 93, 17-24. [CrossRef]

52. Gross, E.M. Impact of reoligotrophication in Lake Constance on nutrient content and defensive phenolic compounds in Eurasian watermilfoil. Verh. Int. Verein Limnol. 2009, 30, 897-899. [CrossRef]

53. Fornoff, F.; Gross, E. Induced defense mechanisms in an aquatic angiosperm to insect herbivory. Oecologia 2014, 175, 173-185. [CrossRef] 
54. Hilt, S.; Köhler, J.; Kozerski, H.-P.; van Nes, E.H.; Scheffer, M. Abrupt regime shifts in space and time along rivers and connected lake systems. Oikos 2011, 120, 766-775. [CrossRef]

55. Hilt, S.; Gross, E.M. Can allelopathically active submerged macrophytes stabilise clear-water states in shallow lakes? Basic Appl. Ecol. 2008, 9, 422-432. [CrossRef]

56. Bugbee, G.J.; White, J.C.; Krol, W.J. Control of variable watermilfoil in Bashan Lake, CT with 2,4-D: Monitoring of lake and well water. J. Aquat. Plant Manag. 2003, 41, 18-25.

57. Taiz, L.; Zeiger, E.; Moller, I.M.; Murphy, A. Plant Physiology and Development, 6th ed.; Sinauer: Sunderland, MA, USA, 2014; pp. 1-761.

58. Dülger, E.; Heidbüchel, P.; Schumann, T.; Mettler-Altmann, T.; Hussner, A. Interactive effects of nitrate concentrations and carbon dioxide on the stoichiometry, biomass allocation and growth rate of submerged aquatic plants. Freshw. Biol. 2017, 62, 1094-1104. [CrossRef]

59. Banks, L.K.; Frost, P.C. Biomass loss and nutrient release from decomposing aquatic macrophytes: Effects of detrital mixing. Aquat. Sci. 2017, 79, 881-890. [CrossRef]

60. Demars, B.O.L.; Edwards, A.C. Tissue nutrient concentrations in freshwater aquatic macrophytes: High inter-taxon differences and low phenotypic response to nutrient supply. Freshw. Biol. 2007, 52, 2073-2086. [CrossRef]

61. Dülger, E.; Hussner, A. Differences in the growth and physiological response of eight Myriophyllum species to carbon dioxide depletion. Aquat. Bot. 2017, 139, 25-31. [CrossRef]

62. Beer, S.; Wetzel, R.G. Photosynthesis in submersed macrophytes of a temperate lake. Plant Physiol. 1982, 70, 488-492. [CrossRef]

63. Hempel, M.; Grossart, H.P.; Gross, E.M. Community composition of bacterial biofilms on two submerged macrophytes and an artificial substrate in a pre-alpine lake. Aquat. Microb. Ecol. 2009, 58, 79-94. [CrossRef]

64. Casper, S.J.; Jentsch, H.; Gutte, P. Beiträge zur Taxonomie und Chorologie europäischer Wasser-und Sumpfpflanzen. Hercynia 1980, 17, 365-374.

65. Hussner, A.; van Dam, H.; Vermaat, J.E.; Hilt, S. Comparison of native and neophytic aquatic macrophyte developments in a geothermally warmed river and thermally normal channels. Fund. Appl. Limnol. 2014, 185, 155-165. [CrossRef]

66. Greulich, S.; Bornette, G. Being evergreen in an aquatic habitat with attenuated seasonal contrasts - a major competitive advantage? Plant Ecol. 2003, 167, 9-18. [CrossRef]

67. Petruzzella, A.; Manschot, J.; van Leeuwen, C.H.A.; Grutters, B.M.C.; Bakker, E.S. Mechanisms of invasion resistance of aquatic plant communities. Front. Plant Sci. 2018, 9. [CrossRef] [PubMed]

68. Schwoerer, T.; Morton, J.M. Human dimensions of aquatic invasive species in Alaska: Lessons learned while integrating economics, management and biology to incentivize early detection and rapid response. In Alaska: Economic, Environmental, and Social Issues; Nova Science Publishers Inc.: Hauppauge, NY, USA, 2018; pp. 1-46.

69. Lodge, D.M. Herbivory on freshwater macrophytes. Aquat. Bot. 1991, 41, 195-224. [CrossRef]

70. Newman, R.M. Invited review—Biological control of Eurasian watermilfoil by aquatic insects: Basic insights from an applied problem. Arch. Hydrobiol. 2004, 159, 145-184. [CrossRef]

71. Newman, R.M. Herbivory and detritivory on fresh-water macrophytes by invertebrates: A review. J. N. Am. Benthol. Soc. 1991, 10, 89-114. [CrossRef]

72. Wimmer, W.; Sprick, P. Records of weevils (Coleoptera: Curculionidae) on Myriophyllum species, with special regard to M. heterophyllum MICHAUX, in Lower Saxony, Germany. Braunschw. Naturk. Schr. 2000, 6, 123-130.

73. Newman, R.M.; Gross, E.M.; Wimmer, W.; Sprick, P. Life history and developmental performance of the Eurasian milfoil weevil, Eubrychius velutus (Coleoptera: Curculionidae). Coleopt. Bull. 2006, 60, 170-176. [CrossRef]

74. Marko, M.D.; Newman, R.M.; Gleason, F.K. Chemically mediated host-plant selection by the milfoil weevil: A freshwater insect-plant interaction. J. Chem. Ecol. 2005, 31, 2857-2876. [CrossRef]

75. Gross, E.M.; Johnson, R.L.; Hairston, N.G., Jr. Experimental evidence for changes in submersed macrophyte species composition caused by the herbivore Acentria ephemerella (Lepidoptera). Oecologia 2001, 127, 105-114. [CrossRef]

76. Johnson, R.L.; Gross, E.M.; Hairston, N.G., Jr. Decline of the invasive submersed macrophyte Myriophyllum spicatum (Haloragaceae) associated with herbivory by larvae of Acentria ephemerella (Lepidoptera). Aquat. Ecol. 1998, 31, 273-282. [CrossRef] 
77. Shearer, J.F. A historical perspective of pathogen biological control of aquatic plants. Weed Technol. 2010, 24, 202-207. [CrossRef]

78. Al-Sammak, M.A.; Hoagland, K.D.; Cassada, D.; Snow, D.D. Co-occurrence of the cyanotoxins BMAA, DABA and anatoxin-a in Nebraska reservoirs, fish, and aquatic plants. Toxins 2014, 6, 488-508. [CrossRef] [PubMed]

79. Kuntz, K.; Heidbuechel, P.; Hussner, A. Effects of water nutrients on regeneration capacity of submerged aquatic plant fragments. Ann. Limnol. 2014, 50, 155-162. [CrossRef]

80. Heidbuechel, P.; Hussner, A. Fragment type and water depth determine the regeneration and colonization success of submerged aquatic macrophytes. Aquat. Sci. 2019, 81. [CrossRef]

81. Johnson, L.E.; Ricciardi, A.; Carlton, J.T. Overland dispersal of aquatic invasiv species: A risk assessment of transient recreational boating. Ecol. Appl. 2001, 11, 1789-1799. [CrossRef]

82. García-Álvarez, A.; van Leeuwen, C.H.A.; Luque, C.J.; Hussner, A.; Vélez-Martín, A.; Pérez-Vázquez, A.; Green, A.J.; Castellanos, E.M. Internal transport of alien and native plants by geese and ducks: An experimental study. Freshw. Biol. 2015, 60, 1316-1329. [CrossRef]

83. Coughlan, N.E.; Kelly, T.C.; Davenport, J.; Jansen, M.A.K. Humid microclimates within the plumage of mallard ducks (Anas platyrhynchos) can potentially facilitate long distance dispersal of propagules. Acta Oecol. 2015, 65-66, 17-23. [CrossRef]

84. Barnes, M.A.; Jerde, C.L.; Keller, D.; Chadderton, W.L.; Howeth, J.G.; Lodge, D.M. Viability of aquatic plant fragments following desiccation. Invasive Plant Sci. Manag. 2013, 6, 320-325. [CrossRef]

85. Heidbuechel, P.; Jahns, P.; Hussner, A. Chlorophyll fluorometry sheds light on the role of desiccation resistance for vegetative overland dispersal of aquatic plants. Freshw. Biol. 2019, 64, 1401-1415. [CrossRef]

86. Milfoil Prevention. Available online: http://www.gmcg.org/advocacy/milfoil-prevention/ (accessed on 27 February 2020).

87. EASIN. Available online: https://easin.jrc.ec.europa.eu/easin (accessed on 27 February 2020).

88. Faulkner, K.T.; Robertson, M.P.; Wilson, J.R.U. Stronger regional biosecurity is essential to prevent hundreds of harmful biological invasions. Glob. Chang. Biol. 2020, 26, 2449-2462. [CrossRef]

89. Hussner, A.; Stiers, I.; Verhofstad, M.J.J.M.; Bakker, E.S.; Grutters, B.M.C.; Haury, J.; van Valkenburg, J.L.C.H.; Brundu, G.; Newman, J.; Clayton, J.S.; et al. Management and control methods of invasive alien freshwater aquatic plants: A review. Aquat. Bot. 2017, 136, 112-137. [CrossRef]

90. Louda, S.M.; Stiling, P. The double-edged sword of biological control in conservation and restoration. Conserv. Biol. 2004, 18, 50-53. [CrossRef]

91. Ray, P. Microbial agents for control of aquatic weeds and their role in integrated management. CAB Rev. 2013, 8. [CrossRef]

92. Gassmann, A.; Cock, M.J.W.; Shaw, R.; Evans, H.C. The potential for biological control of invasive alien aquatic weeds in Europe: A review. Hydrobiologia 2006, 570, 217. [CrossRef]

93. Mafokoane, D.L.; Oberholzer, I.G.; Hill, M.P. The biology and laboratory host range of the weevil, Listronotus marginicollis (Hustache) (Coleoptera: Curculionidae), a natural enemy of the invasive aquatic weed, parrot's feather, Myriophyllum aquaticum (Velloso) Verde (Haloragaceae): Short communication. Afr. Entomol. 2007, 15, 385-390.

94. Havel, J.E.; Knight, S.E.; Maxson, K.A. A field test on the effectiveness of milfoil weevil for controlling Eurasian watermilfoil in Wisconsin lakes. Hydrobiologia 2017, 800, 81-97. [CrossRef]

95. Newman, R.M.; Inglis, W.G. Distribution and abundance of the milfoil weevil, Euhrychiopsis lecontei, in Lake Minnetonka and relation to milfoil harvesting. J. Aquat. Plant Manag. 2009, 47, 21-25.

96. Ward, D.M.; Newman, R.M. Fish predation on Eurasian watermilfoil (Myriophyllum spicatum) herbivores and indirect effects on macrophytes. Can. J. Fish. Aquat. Sci. 2006, 63, 1049-1057. [CrossRef]

97. Marko, M.D.; White, J.C. Direct comparison of herbicidal or biological treatment on Myriophyllum spicatum control and biochemistry. Front. Plant Sci. 2018, 871. [CrossRef]

98. Havel, J.E.; Knight, S.E.; Miazga, J.R. Abundance of milfoil weevil in Wisconsin lakes: Potential effects from herbicide control of Eurasian watermilfoil. Lake Reserv. Manag. 2017, 33, 270-279. [CrossRef]

99. Kasinak, J.-M.E.; Bishop, C.J.; Wright, R.A.; Wilson, A.E. Grass carp do not consume the nuisance benthic cyanobacterium, Lyngbya wollei. J. Aquat. Plant Manag. 2015, 53, 74-80.

100. Yu, J.; Zhen, W.; Guan, B.; Zhong, P.; Jeppesen, E.; Liu, Z. Dominance of Myriophyllum spicatum in submerged macrophyte communities associated with grass carp. Knowl. Manag. Aquat. Ecosyst. 2016. [CrossRef] 
101. Shearer, J.F.; Durham, B.D.; Harms, N. Screening of biological control pathogens isolated from Eurasian watermilfoil. J. Aquat. Plant Manag. 2011, 49, 118-121.

102. Verma, U.; Charudattan, R. Host range of Mycoleptodiscus terrestris, a microbial herbicide candidate for Eurasian Watermilfoil, Myriophyllum spicatum. Biol. Control 1993, 3, 271-280. [CrossRef]

103. Getsinger, K.D.; Netherland, M.D.; Grue, C.E.; Koschnick, T.J. Improvements in the use of aquatic herbicides and establishment of future research directions. J. Aquat. Plant Manag. 2008, 46, 32-41.

104. Beets, J.; Heilman, M.; Netherland, M.D. Large-scale mesocosm evaluation of florpyrauxifen-benzyl, a novel arylpicolinate herbicide, on Eurasian and hybrid watermilfoil and seven native submersed plants. J. Aquat. Plant Manag. 2019, 57, 49-55.

105. Parks, S.R.; McNair, J.N.; Hausler, P.; Tyning, P.; Thum, R.A. Divergent responses of cryptic invasive watermilfoil to treatment with auxinic herbicides in a large Michigan lake. Lake Reserv. Manag. 2016, 32, 366-372. [CrossRef]

106. Glomski, L.M.; Netherland, M.D. Use of a small-scale primary screening method to predict effects of flumioxazin and carfentrazone-ethyl on native and invasive, submersed plants. J. Aquat. Plant Manag. 2013, $51,45-48$.

107. Hussner, A.; Nehring, S.; Hilt, S. From first reports to successful control: A plea for improved management of alien aquatic plant species in Germany. Hydrobiologia 2014, 737, 321-331. [CrossRef]

108. Cabomba and Myriophyllum in Trade: What's in a Name? Robson Meeting Proceedings 2005. Available online: http://www.robsonmeeting.org/ (accessed on 28 February 2020).

109. Ghahramanzadeh, R.; Esselink, G.; Kodde, L.P.; Duistermaat, H.; Van Valkenburg, J.; Marashi, S.H.; Smulders, M.J.M.; Van De Wiel, C.C.M. Efficient distinction of invasive aquatic plant species from non-invasive related species using DNA barcoding. Mol. Ecol. Resour. 2013, 13, 21-31. [CrossRef]

110. Bruckerhoff, L.; Havel, J.; Knight, S. Survival of invasive aquatic plants after air exposure and implications for dispersal by recreational boats. Hydrobiologia 2015, 746, 113-121. [CrossRef]

111. Johnstone, I.M.; Coffey, B.T.; Howard-Williams, C. The role of recreational boat traffic in interlake dispersal of macrophytes: A New Zealand case study. J. Environ. Manag. 1985, 20, 263-279.

112. CABI. Datasheet Myriophyllum heterophyllum (Broadleaf Watermilfoil). Available online: https://www.cabi. org/isc/datasheet/34940\#REF-DDB-27 (accessed on 14 March 2020).

113. Stop Aquatic Hitchhikers! Available online: https://www.fws.gov/fisheries/ans/pdf_files/Stop_Aquatic_ Hitchikers_factsheet.pdf (accessed on 26 February 2020).

114. Stop Aquatic Hitchhikers. Available online: http://www.env.gov.bc.ca/fw/fish/regulations/docs/1011/fa_ AquaticHitchhikers.pdf (accessed on 26 February 2020).

115. Check, Clean, Dry. Available online: http://www.nonnativespecies.org/checkcleandry/ (accessed on 26 February 2020).

116. Be Plant Wise. Available online: http://www.nonnativespecies.org/beplantwise/ (accessed on 26 February 2020).

117. Hippolite, J.; Te Kurapa, T.W.M. Aquatic Pest Report 2018; Bay of Plenty Regional Council, Ed.; Environmental Publication: Whakatane, New Zealand, 2018.

118. Lake Stewards of Maine. Available online: https://www.lakestewardsofmaine.org/ (accessed on 27 February 2020).

119. Bleu Laurentides. Available online: https://crelaurentides.org/dossiers/eau-lacs/bleu-laurentides (accessed on 27 February 2020).

(C) 2020 by the authors. Licensee MDPI, Basel, Switzerland. This article is an open access article distributed under the terms and conditions of the Creative Commons Attribution (CC BY) license (http://creativecommons.org/licenses/by/4.0/). 